\title{
IMPACT OF WRF-3DVAR DATA ASSIMILATION ON THE PREDICTION OF RAINFALL OVER SOUTHERN BRAZIL
}

\author{
V.C. Beck, Y. Yamasaki, F.P. Härter
}

\begin{abstract}
The procedure to combine mathematical models with noise data, in order to improve numerical weather forecasting by statistical methods, is an important and challenging meteorology research field, known as data assimilation. The 3DVAR approach, state of the art in data assimilation technique, is applied in this study. The aim of present development is to evaluate the results of the data assimilation from INMET automatic weather stations and atmospheric soundings in the weather forecast produced by WRF model. The region of interest is the South of Brazil. The specific aim is to evaluate the assimilation procedure of two precipitation events occurred in 2012. This study is especially important, because the INMET automatic weather stations data are not transmitted by GTS. Therefore, these data were not assimilated by prediction systems generated by global models, such as GFS, which provides initial and boundary conditions for regional models, such as WRF. The results showed that the WRF with data assimilation procedure, reproduces satisfactorily the true synoptic scenario given by GFS model in the two cases evaluated, and produces better forecasts then WRF without data assimilation. The thermodynamic analysis showed that the WRF with data assimilation producing vertical profiles of air temperature and dew point temperature very close to the observed profiles. Additional experiments indicate that data assimilated from other sources, in addition to the INMET automatic weather stations and atmospheric soundings, as well as the increases of horizontal resolution in the integration of the WRF with inclusion of subset, provide significant improvements in weather forecasting fields.
\end{abstract}

Keywords: data assimilation, 3DVAR, WRF.

\section{Introduction}

A technique that represents the state of the art in meteorological data assimilation is the Three-Dimensional Variational Method (3DVAR). The first applications of this method in meteorology were held at the European Centre for Medium-Range Weather Forecasts (ECMWF) in the 1990s. Since then the method has been extensively studied and applied [1-8]. The Weather Research and Forecasting Model (WRF) is a Numerical Weather Prediction (NWP), widely used for weather forecasting and research purposes [10]. Currently, several research institutions and government agencies contribute to its development.

The WRF model presents a data assimilation module $[2,6]$, which is used to perform this work. In this research the data from automatic weather stations from Brazilian National Institute of Meteorology (INMET), and atmospheric sounding data, available from the website of the University of Wyoming, are assimilated to the domain corresponding to South of Brazil. In addition the data available from the Global Telecommunication System (GTS) are also assimilated. Global Telecommunication System is the core of the World Meteorological Organization (WMO) responsible for providing meteorological data from its member countries.

The aim of this study is to evaluate the results of the data assimilation of INMET automatic stations and atmospheric sounding stations, generated by the 3DVAR method in the WRF model prediction (WRF-3DVAR). This review is proceeded by checking if the assimilation with WRF-3DVAR reproduces the observed synoptic scenario and produces better predictions than the model without assimilation procedure. The evaluation is done in a subjective way by comparing the forecasts produced by the model with data assimilation 
(WRF-3DVAR) to the forecasts produced by the model without data assimilation (WRF). The specific aim is to evaluate the assimilation procedure in predicting of two rainfall events occurred in 2012 in South of Brazil.

The study is especially important, since the data of the INMET automatic weather stations are not broadcasted by the GTS. Therefore, these data are not assimilated in the forecasts generated by the Global Forecast System (GFS), which provides the initial and boundary conditions for regional models, such as WRF. Moreover, the spatial resolution of WRF model $(18 \mathrm{~km})$ is higher than the GFS $(50 \mathrm{~km})$. In order to evaluate the performance of the WRF-3DVAR to southern of Brazil, were analyzed meteorological fields and thermodynamic profiles of the atmosphere.

\section{Material and methods}

The INMET weather station network supplies data to WMO's World Weather Watch program via the international GTS network providing information to national meteorological institutes worldwide. However, the data from INMET, used in this study, are not broadcast by GTS. Therefore, these data are not assimilated by global model which provides the initial and boundary conditions for WRF. In additional experiment SYNOP, METAR, SHIP and BUOY data available to WMO members by GTS were used.

The conversion of INMET weather station and sounding data from ASCII to LITTLE_R format (format required by the data assimilation system of WRF) is done by script wrote in FORTRAN programming language, specially developed for this purpose.

Numerical model is integrated using 35 layers vertically in hybrid sigma-eta coordinate, horizontal domain of 188 by 112 grid points in the east and north directions, in Lambert projection for two spatial resolution: the coarser domain for $18 \mathrm{~km}$ in hydrostatic mode and nested domain for $6 \mathrm{~km}$ in non-hydrostatic mode (time-step $60 \mathrm{~s}$ ). The boundary layer processes are evaluated using the level 2 closure according to Mellor and Yamada [11] and the soil model was formulated as five stratified layers. Precipitation process considers the grid scale scheme including parameterized cloud microphysics. Sea surface temperature, fixed during integration, is obtained from monthly climatic data. During assimilation procedure a 2 hours time-window is applied, centered in the analysis time.

The cases elected to be simulated in this research, include two rainfall events occurring in south of Brazil, caused by a cyclogenesis associated to a cold front with strong baroclinic instability. The first case has generated large amounts of rainfall associated with cyclogenesis on September 18, 2012 and occlusion on September 19, 2012 (Case 1); and the second case has generated rainfall amounts associated with cyclogenesis on November 22, 2012 and occlusion in day November 24, 2012 (Case 2).

The variables analyzed are: 6-hours Precipitation Totals (RAIN6), 12-hour Precipitation Totals (RAIN12), Reduction of Pressure to Sea Level (PRES) and vertical profiles of Surface Air Temperature (TC) and the Dew Point Temperature (TD). 


\section{Results and discussion}

It will next be shown the results obtained from the processing of WRF and WRF3DVAR for the two cases. Regarding to location, RAIN6 forecasted by WRF and WRF3DVAR to Case 1, were underestimated and poorly reproduced. It was showed a delay in the precipitating core forecasted by WRF-3DVAR comparing to WRF.

In case 2, is shown a significant improvement in the amount and localization of rainfall forecasted by WRF-3DVAR comparing to WRF. The ground truth are 82 rain gauge from INMET. The Fig. 1 shows the RAIN6 predicted from WRF-3DVAR to midnight on November 24, 2012.

The large errors in RAIN6 forecasted by both, WRF and WRF-3DVAR, led the authors to investigate the RAIN12. For case 1, the results were similar to those obtained for RAIN6. Otherwise, for the second case, the amount and location of RAIN12 provided by the WRF3DVAR were quite well reproduced. The Fig. 2 shows the RAIN12 predicted from WRF3DVAR to midnight on November 24, 2012.

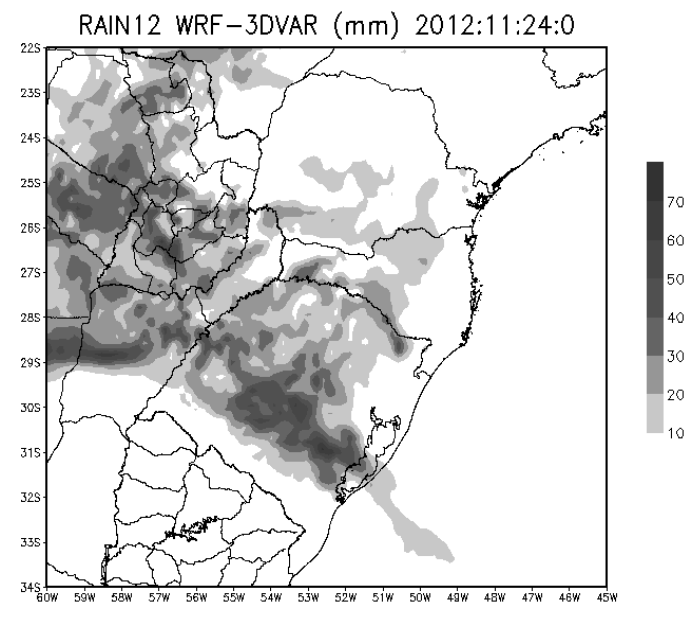

GraDs: COLA/IGES

Fig. 2. RAIN12 predicted from WRF-3DVAR to midnight on November 24, 2012

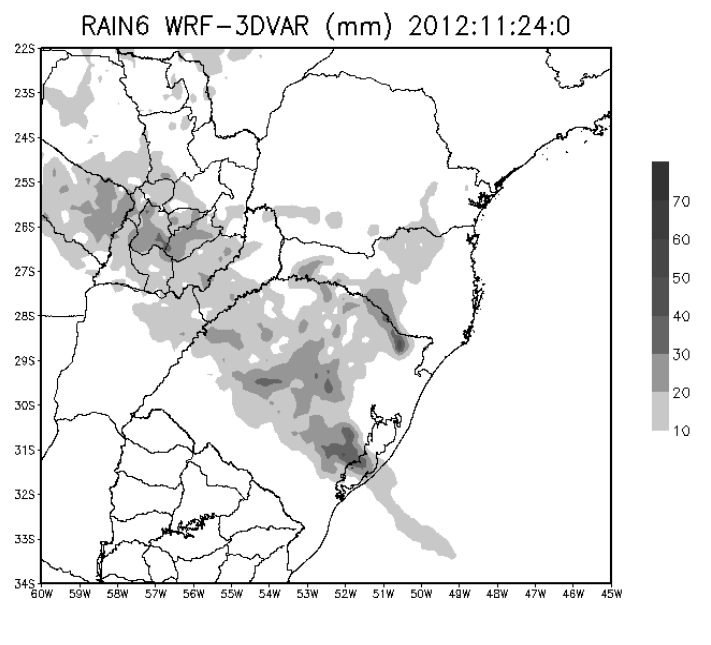

Fig. 1. RAIN6 predicted from WRF-3DVAR to midnight on November 24, 2012

A second experiment was performed in order to verify the results of assimilation by WRF-3DVAR from other source of data (144 SYNOP, 77 METAR, 8 SHIP and 2 BUOY). It 
was carry out for nested grids. A nest is a finer-resolution model run. It is embedded simultaneously within a coarser-resolution model run. In this case, the parental grid has 18 $\mathrm{km}$, covering the entire Southern Region of Brazil and the nested grid has $6 \mathrm{~km}$ covering only the state of Rio Grande do Sul. The large amounts of RAIN12 near to Foz do Iguaçu city, generated by assimilation of additional data, are in agreement with ground truth.

Table 1

RAIN12 observed from INMET stations

\begin{tabular}{|l|c|}
\hline \multicolumn{1}{|c|}{ CITY } & $\begin{array}{c}\text { RAIN12 observed } \\
\text { 00:00 UTC 24/11/2012, mm }\end{array}$ \\
\hline Porto Alegre & 0.0 \\
\hline Santa Maria & 36.8 \\
\hline Rio Grande & 0.0 \\
\hline Joaçaba & 2.2 \\
\hline Florianópolis & 1.6 \\
\hline Foz do Iguaçu & 40.2 \\
\hline Curitiba & 0.0 \\
\hline
\end{tabular}

It is noteworthy that the location of some core of rainfall on the border between Rio Grande do Sul and Uruguay and in some cities of Rio Grande do Sul (Table 1) and Uruguay were better represented in the experiment with high spatial resolution. The surface pressure tendency is an indication of the direction and development of a cyclonic disturbance and it is associated to an increase of rainfall rates in low pressure area. The results show that this scenario was well represented by WRF-3DVAR in Case 1 as well Case 2.

Regarding the vertical profiles of air temperature, TC and TD predicted by WRF3DVAR are quite close to those observed in Curitiba city above $200 \mathrm{hPa}$ and from surface to $500 \mathrm{hPa}$ in Porto Alegre city in Case 1; from surface to $500 \mathrm{hPa}$ in Curitiba city, Foz do Iguaçu city and Florianópolis city; and near the surface in Porto Alegre city in Case 2.

\section{Conclusion}

The WRF-3DVAR satisfactorily reproduced the synoptic scenario in the two cases analyzed and the forecasting produced by WRF-3DVAR is markedly better than this one produced by WRF, in the cases studied. However, RAIN6 was poorly reproduced by the model with and without data assimilation in Case 1, duo the spin up problem $[9,10]$. The data assimilated from other sources, in addition to the INMET automatic weather stations and soundings stations, as well as the increases of horizontal resolution, provides significant improvements in weather forecasting fields.

This work was supported by Coordenação de Aperfeiçoamento de Pessoal de Nivel Superior (CAPES), Brazil.

\section{References}

1. Rabier, F. Recent Experiments on 4D-Var and First Results from a Simplified Kalman Filter // F. Rabier, J-F. Mahfouf, M. Fischer, H. Järvinen, A. Simmon, F. Bouttier, P. Coutier, M. Hamrud, J. Haseler, A. Hollingsworth, L. Isaksen, 
E. Klinker, S. Saarinen, C. Temperton, J-N. Thépaut, P. Undén, D. Vasiljevic // ECMWF Newsletter. - 1998. - Vol. 81. - P. 8-16.

2. Barker, D. M. A Three-Dimension (3DVAR) Data Assimilation System For Use With MM5: Implementation and Initial Results / D.M. Barker, W. Huang, Y.-R. Guo, Q. N. Xiao // Monthly Weather Review. - 2004. - Vol. 132. - P. 897-914.

3. Meng, Z. Tests of an Ensemble Kalman Filter for Mesoscale and Regional-scale Data Assimilation. Part III: Comparison with 3DVAR in a Real-data Case Study / Z. Meng, F. Zhang // Monthly Weather Review. - 2008. - Vol. 136. - P. 522-540.

4. Sugimoto, S. An Examination of WRF 3DVAR Radar Data Assimilation on Its Capability in Retrieving Unobserved Variables and Forecasting Precipitation through Observing System Simulation Experiments / S. Sugimoto, N.A. Crook, J. Sun, Q. Xiao, D.M. Barker // Monthly Weather Review. - 2009. - Vol. 137. - P. 40114029 .

5. Rakesh, V. Intercomparison of the performance of MM5/WRF with and without data assimilation in short-range forecast applications over the Indian region / V. Rakesh, R. Singh, P.C. Joshi // Meteorology and Atmospherical Physics. - 2009. - Vol. 105. P. 133-155.

6. Barker, D.M. The weather Research and Forecasting Model's Community Variational / Ensemble Data Assimilation System: WRFDA / D.M. Barker, W. Huang, Z. Liu, T. Auligné, X. Zhang, S. Rugg, R. Ajjaji, A. Bourgeois, J. Bray, Y. Chen, M. Demirtas, Y.-R. Guo, T. Henderson, W. Huang, H.-C. Lin, J. Michalakes, S. Rizvi, X. Zhang // Bulletin of American Meteorological Society. - 2012. - Vol. 93. - P. 831-843.

7. Huang, X.-Y. Four-Dimensional Variational Data Assimilation for WRF: Formulation and Preliminary Results / X.-Y. Huang, Q. Xiao, D.M. Barker, X. Zhang, J. Michalakes, W. Huang, T. Henderson, J. Bray, Y. Chen, Z. Ma, J. Dudhia, Y. Guo, X. Zhang, D.-J. Won, H.-C. Lin, Y. H. Kuo // Monthley Weather Review. 2009. -Vol. 137. - P. 299-314.

8. Routray, A. Impact of Doppler weather radar data on numerical forecast of Indian monsoon depressions / A. Routray, U.C. Mohanty, S.R.H. Rizvi, D. Niyogi, K. K. Osuri, D. Pradhan // Quarterly Journal of Royal Meteorological Society. 2010. - Vol.136. - P. 1836-1850.

9. Oyama, M.D. Estudo Preliminar sobre o tempo de "Spin Up" da umidade do solo no modelo climático do CPTEC / M.D. Oyama, E.J.P. Rocha, C.A. Nobre // In Proceedings: XI Congresso Brasileiro de Meteorologia, 16-20 de Outubro, 2000, Rio de Janeiro. - P. 1085-1094.

10. Wang, W. WRF-ARW V3: User's Guide / W. Wang, C. Beezley, M. Duda, et al. URL: http://www.mmm.ucar.edu/wrf/users (accessed: 11.01.2013).

11. Mellor, G.L. A hierarchy of turbulent closure models for planetary boundary layers / G.L. Mellor, T.Yamada // Journal of Atmospheric Science. - 1974. - Vol. 31 P. 1791-1806.

Vinicius Carvalho Beck, student of Graduate Program in Meteorology, Pelotas Federal University (Pelotas, RS, Brazil), vonoco@gmail.com. 
Yoshihiro Yamasaki, professor, Faculty of Meteorology, Pelotas Federal University (Pelotas, RS, Brazil), yamasaki@fis.ua.pt.

Fabricio Pereira Harter, professor, Faculty of Meteorology, Pelotas Federal University (Pelotas, RS, Brazil), fabricio.harter@ufpel.edu.br.

Received 11 October 2013.

Bulletin of the South Ural State University Series "Computational Mathematics and Software Engineering" 2014, vol. 3, no. 2, pp. 122-129

УДК 551.509, 004.94

\section{ВЛИЯНИЕ АССИМИЛЯЦИИ ДАННЫХ WRF-3DVAR НА ПРОГНОЗ ЛИВНЕВЫХ ОСАДКОВ НАД ЮЖНОЙ ЧАСТЬЮ БРАЗИЛИИ}

В.К.Бек, И. Ямазаки, Ф.П. Хартер

Рассмотрена процедура подачи на вход математической модели данных, сопровождаемых шумом, с целью улучшения статистическими методами моделирования метеорологических полей при прогнозировании погоды. Этот процесс, называемый ассимиляцией данных, является передовым методом в моделировании метеорологических полей. Подход 3DVAR, применяемый в представленном исследовании, является современной технологией ассимиляции данных. Поставлена цель оценить результаты ассимиляции данных сети автоматических станций и данных атмосферного зондирования Бразильского национального метеорологического института (INMET) для прогноза погоды с помощью модели WRF. Регион исследования - южная часть Бразилии. В частности, рассматриваются два события 2012 г., связанные с интенсивными осадками. Представленное исследование важно, поскольку данные автоматических станций INMET не поступают в глобальную телекоммуникационную систему и, следовательно, не используются при производстве прогноза глобальными прогностическими моделями, такими как GFS, которые рассчитывают начальные и граничные условия для региональных моделей, например, WRF. Результаты исследования показывают, что модель WRF с использованием ассимиляции данных в обоих рассмотренных случаях удовлетворительно воспроизводит синоптическую ситуацию, предоставляемую глобальной моделью GFS, и это воспроизведение лучше, чем без использования ассимиляции данных. Термодинамический анализ демонстрирует, что WRF c использованием ассимиляции данных воспроизводит вертикальные профили температуры и точки росы очень близко к наблюдаемым. Дополнительные эксперименты показывают, что усваиваемые данные из других источников в дополнении к данным INMET, а также увеличение пространственного разрешения по горизонтали при интегрировании в WRF c включением дополнительных наборов приводит к значительному улучшению прогнозируемых полей метеорологических величин.

Ключевые слова: ассимилячия данных, 3DVAR, WRF.

\section{Литература}

1. Rabier, F. Recent Experiments on 4D-Var and First Results from a Simplified Kalman Filter // F. Rabier, J-F. Mahfouf, M. Fischer, H. Järvinen, A. Simmon, 
F. Bouttier, P. Coutier, M. Hamrud, J. Haseler, A. Hollingsworth, L. Isaksen, E. Klinker, S. Saarinen, C. Temperton, J-N. Thépaut, P. Undén, D. Vasiljevic // ECMWF Newsletter. - 1998. - Vol. 81. - P. 8-16.

2. Barker, D. M. A Three-Dimension (3DVAR) Data Assimilation System For Use With MM5: Implementation and Initial Results / D.M. Barker, W. Huang, Y.-R. Guo, Q. N. Xiao // Monthly Weather Review. - 2004. - Vol. 132. - P. 897-914.

3. Meng, Z. Tests of an Ensemble Kalman Filter for Mesoscale and Regional-scale Data Assimilation. Part III: Comparison with 3DVAR in a Real-data Case Study / Z. Meng, F. Zhang // Monthly Weather Review. - 2008. - Vol. 136. - P. 522-540.

4. Sugimoto, S. An Examination of WRF 3DVAR Radar Data Assimilation on Its Capability in Retrieving Unobserved Variables and Forecasting Precipitation through Observing System Simulation Experiments / S. Sugimoto, N.A. Crook, J. Sun, Q. Xiao, D.M. Barker // Monthly Weather Review. - 2009. - Vol. 137. - P. 40114029 .

5. Rakesh, V. Intercomparison of the performance of MM5/WRF with and without data assimilation in short-range forecast applications over the Indian region / V. Rakesh, R. Singh, P.C. Joshi // Meteorology and Atmospherical Physics. - 2009. - Vol. 105. P. 133-155.

6. Barker, D.M. The weather Research and Forecasting Model's Community Variational / Ensemble Data Assimilation System: WRFDA / D.M. Barker, W. Huang, Z. Liu, T. Auligné, X. Zhang, S. Rugg, R. Ajjaji, A. Bourgeois, J. Bray, Y. Chen, M. Demirtas, Y.-R. Guo, T. Henderson, W. Huang, H.-C. Lin, J. Michalakes, S. Rizvi, X. Zhang // Bulletin of American Meteorological Society. - 2012. - Vol. 93. - P. 831-843.

7. Huang, X.-Y. Four-Dimensional Variational Data Assimilation for WRF: Formulation and Preliminary Results / X.-Y. Huang, Q. Xiao, D.M. Barker, X. Zhang, J. Michalakes, W. Huang, T. Henderson, J. Bray, Y. Chen, Z. Ma, J. Dudhia, Y. Guo, X. Zhang, D.-J. Won, H.-C. Lin, Y. H. Kuo // Monthley Weather Review. 2009. -Vol. 137. - P. 299-314.

8. Routray, A. Impact of Doppler weather radar data on numerical forecast of Indian monsoon depressions / A. Routray, U.C. Mohanty, S.R.H. Rizvi, D. Niyogi, K. K. Osuri, D. Pradhan // Quarterly Journal of Royal Meteorological Society. 2010. - Vol.136. - P. 1836-1850.

9. Oyama, M.D. Estudo Preliminar sobre o tempo de "Spin Up" da umidade do solo no modelo climático do CPTEC / M.D. Oyama, E.J.P. Rocha, C.A. Nobre // In Proceedings: XI Congresso Brasileiro de Meteorologia, 16-20 de Outubro, 2000, Rio de Janeiro. - P. 1085-1094.

10. Wang, W. WRF-ARW V3: User's Guide / W. Wang, C. Beezley, M. Duda, et al. URL: http://www.mmm.ucar.edu/wrf/users (accessed: 11.01.2013).

11. Mellor, G.L. A hierarchy of turbulent closure models for planetary boundary layers / G.L. Mellor, T.Yamada // Journal of Atmospheric Science. - 1974. - Vol. 31 P. 1791-1806. 
V.C. Beck, Y. Yamasaki, F.P. Härter

Винисиус Карвальо Бек, магистрант метеорологического факультета, Федеральный университет г. Пелотас, Бразилия.

Йошихиро Ямазаки, преподаватель метеорологического факультета, Федеральный университет г. Пелотас, Бразилия.

Фабрисио Перейра Хартер, преподаватель метеорологического факультета, Федеральный университет г. Пелотас, Бразилия.

Поступила в редакцию 11 октября 2013 г. 